\title{
Krill oil extract inhibits the migration of human colorectal cancer cells and down- regulates EGFR signalling and PD-L1 expression
}

\author{
Abilasha G. Jayathilake1, Margaret F. Veale ${ }^{1}$, Rodney Brain Luwor ${ }^{2}$, Kulmira Nurgali1 $^{1,3}$ and Xiao Q. Su ${ }^{*}$ (D)
}

\begin{abstract}
Background: The currently available treatments for colorectal cancer (CRC) are often associated with serious sideeffects. Therefore, the development of a novel nutraceutical agent may provide an alternative complementary therapy for CRC. Overexpression of the epidermal growth factor receptor (EGFR) associates with a range of cancers while downregulation of EGFR signalling can inhibit cancer growth. Our previous studies have shown that the free fatty acid extract (FFAE) of krill oil exhibits anti-proliferative and pro-apoptotic properties. This study determines the effects of krill oil extract on the migration of human CRC cells, and its potential role in modulating EGFR signalling pathway and the expression of programmed death ligand 1 (PD-L1).
\end{abstract}

Methods: Human CRC cells, DLD-1 and HT-29 were treated with FFAE of KO at 0.03 and $0.12 \mu \mathrm{L} / 100 \mu \mathrm{L}$ for 8 or 24 h. Cell migration was determined by Boyden chamber migration assay. The expression of EGFR, phosphorylated EGFR (pEGFR), protein kinase B (AKT), phosphorylated AKT (pAKT), extracellular signal regulated kinase (ERK1/2), phosphorylated ERK1/2 (pERK1/2) as well as PD-L1 were assessed by western blotting and immunohistochemistry.

Results: The FFAE of krill oil significantly inhibited cell migration compared to ethanol-treated (vehicle control) cells $(P<0.01$ to $P<0.001)$. At the molecular level, krill oil extract reduced the expression of EGFR, DEGFR $(P<0.001$ for both) and their downstream signalling, pERK1/2 and PAKT $(P<0.01$ to $P<0.001)$ without altering total ERK $1 / 2$ and AKT levels. In addition, the expression of PD-L1 was reduced by 67 to $72 \%(P<0.001)$ following the treatment with krill oil extract.

Conclusion: This study has demonstrated that krill oil may be a potential therapeutic/adjunctive agent for CRC attributed to its anti-migratory effects.. The potential anti-cancer properties of krill oil are likely to be associated with the downregulation of EGFR, pEGFR and their downstream pERK/ERK1/2 and pAKT/AKT signalling pathways along with the downregulation of PD-L1.

Keywords: Krill oil extract, Human colorectal cancer cells, Migration, EGFR, PD-L1

\footnotetext{
* Correspondence: xiao.su@vu.edu.au

${ }^{1}$ Institute for Health and Sport, Victoria University, P.O. Box 14428, Melbourne, Vic 8001, Australia

Full list of author information is available at the end of the article
}

(c) The Author(s). 2020 Open Access This article is licensed under a Creative Commons Attribution 4.0 International License, which permits use, sharing, adaptation, distribution and reproduction in any medium or format, as long as you give appropriate credit to the original author(s) and the source, provide a link to the Creative Commons licence, and indicate if changes were made. The images or other third party material in this article are included in the article's Creative Commons licence, unless indicated otherwise in a credit line to the material. If material is not included in the article's Creative Commons licence and your intended use is not permitted by statutory regulation or exceeds the permitted use, you will need to obtain permission directly from the copyright holder. To view a copy of this licence, visit http://creativecommons.org/licenses/by/4.0/ The Creative Commons Public Domain Dedication waiver (http://creativecommons.org/publicdomain/zero/1.0/) applies to the data made available in this article, unless otherwise stated in a credit line to the data. 


\section{Background}

Colorectal cancer (CRC) is the third most common cancer in men and the second most common cancer in women worldwide [1, 2]. Estimated incidents of new cases exceed 1.8 million per year, causing 862,000 deaths globally each year [3]. The currently available therapies include surgery, chemotherapy, radiotherapy or a combination of them [4]. Complete surgical resection is curative only if the disease is identified at the early stage. However, initial stages of CRC are often asymptomatic and the percentage of stage IV diagnosis is only $20-25 \%$ [5]. Therefore, a high proportion of patients show distant metastases at the time of diagnosis [6]. The most common treatment for the patients with metastatic CRC is chemotherapy [7], and this is associated with serious side-effects [8]. Therefore, an alternative therapy with few or no adverse effects would be desirable.

Long-chain omega-3 polyunsaturated fatty acids (LC n-3 PUFA), eicosapentaenoic acid (EPA, 20:5n-3) and docosahexaenoic acid (DHA, 22:6n-3), commonly found in fish and other seafoods, have shown beneficial effects on several types of cancer including CRC [9]. The positive impacts of LC n-3 PUFA on CRC include inhibiting cell proliferation [10], metastasis and growth [11]. In addition, they improve patients' immune function and reduce the toxicity and side-effects of chemotherapy [12]. Krill oil, extracted from small crustaceans Euphausia surperba from the Antarctic Ocean, is one of the rich sources of LC n-3 PUFA [13]. The LC n-3 PUFA in krill oil are bound to the phospholipids while in fish oil they are bound mainly to the triglycerides [13, 14]. It has been suggested that the bioavailability of phospholipid bound n-3 PUFA is higher than those bound to triglycerides and this may lead to more health benefits $[15,16]$. Our previous studies have shown that the free fatty acid extract (FFAE) of krill oil inhibits the proliferation of both CRC and osteosarcoma cells, and induces the apoptosis of CRC cells $[17,18]$. We also found that the antiproliferative property of krill oil is comparable with a chemotherapeutic drug, Oxaliplatin [19]. Furthermore, we have reported that the anti-proliferative property of krill oil is associated with the activation of caspase- 9 and caspase-3 leading to DNA damage in the CRC cells. Preliminary study by Zhu et al. also observed that krill oil treatment results in a time-dependent inhibition of CRC cell growth [20].

Epidermal growth factor receptor (EGFR) is a member of the erythroblastosis oncogene B (ErbB)/ family of receptor protein tyrosine kinase (TK) that transmits growth-inducing signals to cells [21]. The EGFR is stimulated by its interaction with the corresponding ligands. It then phosphorylates and activates several downstream signalling pathways including Ras/Raf/mitogen-activated extracellular signal-regulated kinase (Ras/Raf/MEK/
ERK), phosphoinositide 3-kinase/ protein kinase B/ mammalian target of rapamycin (PI3K/AKT/mTOR). The overexpression of EGFR that correlates with cancer cell proliferation, tumour growth, invasion and metastasis is common in human cancers including CRC [22]. Therefore, the inhibition of EGFR signalling has been reported as an important target in cancer therapy [23]. Furthermore, it was found that the activation of EGFR and its downstream AKT signalling pathway is associated with an increased expression of the programmed death ligand 1 (PD-L1) protein [24, 25]. PD-L1, through its immune suppressive properties, plays multiple roles in several types of cancer such as, accelerating tumour progression, transmitting intracellular anti-apoptotic signals and improving cancer cell survival [26, 27]. The aims of this study were to investigate the effect of FFAE of krill oil on migration of human CRC cells; and determine the role of krill oil extract in modulation of EGFR and its downstream signalling pathways.. Furthermore, the efficacy of krill oil extract on PD-L1 expression was assessed.

\section{Methods \\ Cell lines and culture conditions}

The human colon adenocarcinoma cell lines, DLD-1 and HT-29 were obtained from the American Tissue Culture Collection (ATCC), Manassas, VA, USA (Catalogue No. CCL-221, HTB-38). Both cell lines were maintained in RPMI1640 medium (Sigma Aldrich, Castle Hill, NSW, Australia) supplemented with foetal calf serum (FCS, 10\%) (Hyclone Quantum Scientific, Clayton South, VIC, Australia), glutamine (10 mM), 4-2-hydroxyethyl-1piperazineethanesulfonic acid, sodium pyruvate $(10 \mathrm{mM})$ and penicillin $(100 \mathrm{U} / \mathrm{mL}) /$ streptomycin $(100 \mu \mathrm{g} / \mathrm{mL})$ (Sigma Aldrich, Castle Hill, NSW, Australia). Cells were grown at $37^{\circ} \mathrm{C}$ in $5 \% \mathrm{CO}_{2}$ humidified atmosphere. Exponentially growing cells that were $>90 \%$ viable were used for assays.

\section{Extraction of free fatty acids from krill oil}

Free fatty acids were extracted from the krill oil (Swisse Wellness Pty Ltd., Victoria, Australia) following the hydrolysis (saponification) method of Salimon et al. [28]. The extracts were dissolved in $100 \%$ ethanol and stored at $-20{ }^{\circ} \mathrm{C}$. The final treatment solutions contained $<0.1 \%$ ethanol as a solvent.

\section{Cell morphology assay}

DLD-1 and HT-29 cells were seeded and cultured at $3 \times$ $10^{5}$ cells per well in 6-well plates for $24 \mathrm{~h}$. They were then treated with FFAE of krill oil for $24 \mathrm{~h}$ at two concentrations, $0.03 \mu \mathrm{L}$ and $0.12 \mu \mathrm{L} / 100 \mu \mathrm{L}$ (equating to the concentrations of EPA and DHA per $100 \mu \mathrm{L}$ well at $0.13 / 0.06$ and $0.52 / 0.26 \mu \mathrm{M}$, respectively). These two 
concentrations and duration of treatment were selected based on data from our preliminary experiments. All treatments were performed in triplicates and the results were verified through three individual experiments. In all experiments, $0.1 \%$ ethanol was used as a vehicle control. Cell morphology was analysed using the Olympus $1 \times 81(20 \mathrm{X})$ microscope.

\section{Boyden chamber transwell migration assay}

Cell culture was prepared in a 12-well Boyden chamber with filter membranes of $8.0 \mu \mathrm{m}$ pore size (Corning, USA) to determine the cell migration. Cells were treated with serum-free medium for $24 \mathrm{~h}$. A suspension of $1 \times$ $10^{5}$ cells in $200 \mu \mathrm{L}$ of serum-free RPMI 1640 media was added to the upper chamber of each well in the transwell plate. The bottom chambers were filled with $600 \mu \mathrm{L}$ of serum free RPMI 1640 media supplemented with FFAE of krill oil at two dilutions of $0.03 \mu \mathrm{L} / 100 \mu \mathrm{L}$ and $0.12 \mu \mathrm{L} / 100 \mu \mathrm{L}$. The control well (vehicle control) was filled with 10\% FCS in culture media and less than 0.1\% ethanol as a chemo attractant. The culture plates were incubated at standard culture conditions for $24 \mathrm{~h}$. The wells and bottom of the transwells in a culture plate were then trypsinised (Fig. 1). The number of migrated cells were counted using a haemocytometer. All treatments were performed in triplicates and each experiment was repeated three times for both cell lines. The results were presented as mean \pm SEM.

\section{Cell apoptosis}

Flow cytometry was used to investigate the cell apoptosis by double staining with annexin V (Cat. 64,906 Bio Legend, Australia) and propidium iodide (PI) (Cat. P4864 Sigma-Aldrich, USA). Briefly, $3 \times 10^{5}$ cell/well in 6-well plates were cultured for $24 \mathrm{~h}$ and then treated with FFAE of krill oil at the concentration of $0.12 \mu \mathrm{L} / 100 \mu \mathrm{L}$ for $8 \mathrm{~h}$. The cells were trypsinised and centrifuged at $1200 \mathrm{rpm}$ at room temperature for $5 \mathrm{~min}$ and the cell pellets were resuspended in $100 \mu \mathrm{L}$ of annexin V Binding Buffer (AVBB) (Australian Bio Search, Western Australia) containing $1 \mu \mathrm{L}$ of PI and $1 \mu \mathrm{L}$ of annexin V- FITC and incubated at room temperature in the dark for $15 \mathrm{~min}$ before $400 \mu \mathrm{L}$ of AVBB was added. Cell apoptosis was detected using a FACS Canto II flow cytometer (BD BioSciences, Palo Alto, USA) and 10,000 cells were collected and analysed per sample. Control cells were treated with $0.1 \%$ ethanol. The data were analysed using the FACS Diva Software (BD Bioscience). PI was used to distinguish live and dead cells. All treatments were performed in duplicates and each experiment was repeated three times for both cell lines. The results were presented as mean \pm SEM.

\section{Immunocytochemistry}

Cells were seeded at a density of $2 \times 10^{4}$ cells/well in 24 well plates with coverslips and incubated for $24 \mathrm{~h}$. The cells were then treated with FFAE of krill oil at the concentration of $0.12 \mu \mathrm{L} / 100 \mu \mathrm{L}$ for $8 \mathrm{~h}$. Immunocytochemistry assay was performed as described in our previous study [19]. Target protein levels were observed using primary antibodies against pEGFR (1:500, rabbit, Cell Signalling, MA, USA), EGFR (1: 500, rabbit, Cell Signalling), pERK1/2 (1:500, rabbit, mAB, 9101, Cell Signalling Technologies, MA, USA) and pAKT (1: 500, rabbit, mAB, 9271, Cell Signalling Technologies, MA, USA). The cells were then incubated with secondary antibodies, Alexa Fluor 594 conjugated anti-rabbit or Alexa Fluor 488 conjugated anti-rabbit (Jackson Immuno Research Laboratories, PA, USA) (diluted 1:250) at room temperature for $2 \mathrm{~h}$. Finally, cells were exposed to DAPI for $2 \mathrm{~min}$ and images were taken with the Eclipse Ti Confocal laser scanning system (Nikon, Tokyo, Japan). The excitation wavelengths for FITC and Alexa Fluor 594 were adjusted to $488 \mathrm{~nm}$ and $559 \mathrm{~nm}$ respectively. Each fluorophore was measured using 8 images taken at 20X magnification with a total area of 2 $\mathrm{mm}^{2}$. All images were then calibrated for a minimum basal fluorescence and converted into binary. Fluorescence intensity was measured using Image J software (National Institute of Health, USA). All treatments were performed in triplicates and the results were verified in at least three individual experiments.

\section{Western blotting}

The expression of pEGFR/EGFR, pERK/ERK $1 / 2$ and pAKT/AKT proteins was determined in DLD-1 and HT-

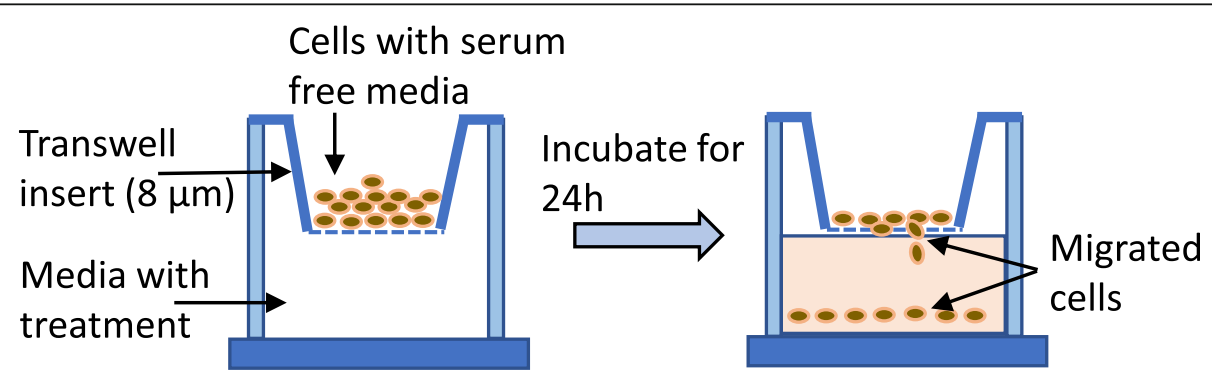

Fig. 1 A schematic diagram of the transwell model 
29 cells treated with FFAE of krill oil at the concentrations of $0.03 \mu \mathrm{L}$ and $0.12 \mu \mathrm{L} / 100 \mu \mathrm{L}$ for $8 \mathrm{~h}$ and the results were compared with the ethanol vehicle control. Two additional steps were performed for pEGFR/EGFR expression: (i) cells were incubated with anti-EGF (Thermo Fisher Scientific) antibodies (1:1000 dilution with cell culture media) for $1 \mathrm{~h}$ before the FFAE of krill oil was added or cetuximab (Merck, Darmstadt, Germany) treatments, including the ethanol vehicle control; (ii) cetuximab $(20 \mu \mathrm{g} / \mathrm{mL})$ treated cells were used as a positive control. Western blotting was performed as described in our previous study [19]. Briefly, cell lysates were prepared and aliquots of each $(12 \mu \mathrm{g})$ and separated using 4 to $20 \%$ sodium dodecyl sulphate (SDS)/ polyacrylamide gel electrophoresis and the separated proteins were transferred to polyvinylidene fluoride (PVDF) membranes (Trans-Blot Turbo Transfer System, Bio Rad, USA). The membrane was incubated with primary antibodies rabbit anti-human against pEGFR (1:1000, Cell Signaling Technology, MA, USA), EGFR (1:1000, Cell Signaling Technology, MA, USA), pERK 1/ 2 (1:1000, rabbit, mAB, 9101, Cell Signalling Technologies, MA, USA), ERK 1/ 2 (1:1000, rabbit, H72, Cell Signalling Technologies, MA, USA), pAKT (1:1000, rabbit, mAB, 9271, Cell Signalling Technologies, MA, USA), AKT antibody (1:1000, rabbit, mAB, Cell Signaling Technology, MA, USA) and GAPDH as a control (1:2000 dilution, rabbit, Santa Cruz Biotechnology, USA) for overnight at $4{ }^{\circ} \mathrm{C}$. Next the membrane was incubated with secondary antibody, goat anti-rabbit IgG H\&L horseradish peroxidase (HRP) (Abcam, ab6721, MA, USA) at room temperature for $1 \mathrm{~h}$. The protein detection was analysed using enhanced chemiluminescence reagents (ClarityTM Western ECL Substrate, Bio-Rad, USA) and visualised using a FUSION FX Densitometer (Vilber Lourmat, Germany). The expression level of each protein was quantified using Fusion Capt advance FX7 software. All treatments were performed in triplicate and the results were verified through at least three individual experiments.

\section{Statistical analysis}

All data were analysed using SPSS 22 software (IBM, USA). Mixed model ANOVA was used to determine the significance between treatments. The significance of repeated measure at different time points was analysed using one-way ANOVA. Post-hoc analysis was conducted using Tukey HSD test for multiple comparisons. $P<0.05$ was considered as significant. The results were expressed as mean \pm SD in tables or mean \pm SEM in figures.

\section{Results}

Effects of FFAE of krill oil on the viability, migration and apoptosis of CRC cells

Morphological changes of colon cancer cells, DLD-1 and HT-29, treated with low and high doses of FFAE of krill oil, were analysed using fluorescent microscopy with a 20X objective (Olympus 1X-81, Nikon, Japan). As shown in Fig. 2a, the untreated cells displayed normal CRC morphology as indicated by their uniform distribution and confluence. However, the cells treated with FFAE of krill oil at $12 \mu \mathrm{L} / 100 \mu \mathrm{L}$ have exhibited obvious morphological changes, including the loss of cell adhesion, membrane shrinkage, shape alteration as well as decreased cell numbers compared to the control group.

The effect of FFAE of krill oil on the migration of DLD-1 and HT-29 CRC cells was determined using a Boyden chamber transwell migration assay (Fig. 2b). The lower concentration of FFAE of krill oil $(0.03 \mu \mathrm{L} / 100 \mu \mathrm{L})$ reduced the migration of DLD-1 cells by $31.4 \pm 1.1 \%$ $(P<0.01)$ while the higher concentration $(0.12 \mu \mathrm{L} /$ $100 \mu \mathrm{L})$ reduced the migration by $94.4 \pm 1.0 \%(P<0.001)$ following $24 \mathrm{~h}$ of krill oil extract treatment compared with the ethanol control. HT-29 cells treated with lower concentration of FFAE of krill oil at $0.03 \mu \mathrm{L} / 100 \mu \mathrm{L}$ reduced the cell migration by $20.6 \pm 1.1 \%(\mathrm{P}<0.01)$ while the higher concentration at $0.12 \mu \mathrm{L} / 100 \mu \mathrm{L}$ resulted in $90.9 \pm 2.3 \%$ reduction of HT-29 cell migration $(P<$ 0.001 ) following $24 \mathrm{~h}$ of treatment.

The effect of FFAE of krill oil on the apoptosis of two human CRC cell lines was investigated using an Annexin V/PI staining and flow cytometry (Fig. 3). The treatments with FFAE of krill oil at $0.12 \mu \mathrm{L} / 100 \mu \mathrm{L}$ resulted in a significant reduction of viable cells (negative to both staining) and a significantly higher apoptosis rate across both CRC cell lines compared to the vehicle control cells. The percentage of apoptosis in DLD-1 and HT-29 cells has increased by approximately 18 to $19.5 \%$ following treatments with FFAE of krill oil for $8 \mathrm{~h}$ compared to ethanol-treated cells (Fig. 3A' and B'). No significant cell necrosis was observed following treatments with krill oil in either cell line compared to ethanol-treated cells.

\section{Expression of pEGFR/EGFR, pERK/ERK 1/2, pAKT/AKT and PD-L1 following treatments with FFAE of krill oil}

The expression of EGFR, pEGFR, pERK/ERK 1/ 2, pAKT/AKT and PD-L1 in DLD-1 and HT-29 cells was determined via western blotting and immunohistochemistry (Figs. 4, 5, 6, 7, and 8). The cells were treated at low $(0.03 \mu \mathrm{L} / 100 \mu \mathrm{L})$ and high $(0.12 \mu \mathrm{L} / 100 \mu \mathrm{L})$ concentrations of FFAE of krill oil for $8 \mathrm{~h}$ respectively before the proteins were extracted.

(A) Morphological changes of DLD-1 and HT-29 cells were observed using phase contrast microscopy at 20X magnification following $24 \mathrm{~h}$ of treatment with FFAE of krill oil compared with ethanol (vehicle control) treatment. Panel a, DLD-1 cells treated with ethanol; Panels b and c, DLD-1 cells treated with FFAE of krill oil at the concentrations of $0.03 \mu \mathrm{L} / 100 \mu \mathrm{L}$ and $0.12 \mu \mathrm{L} / 100 \mu \mathrm{L}$ respectively. Panel a', HT-29 cells treated with ethanol; 

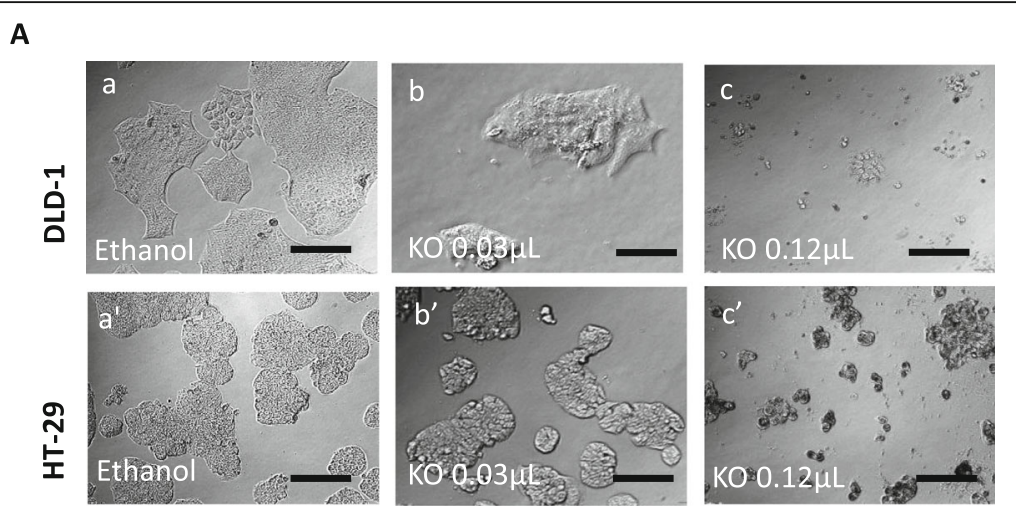

B

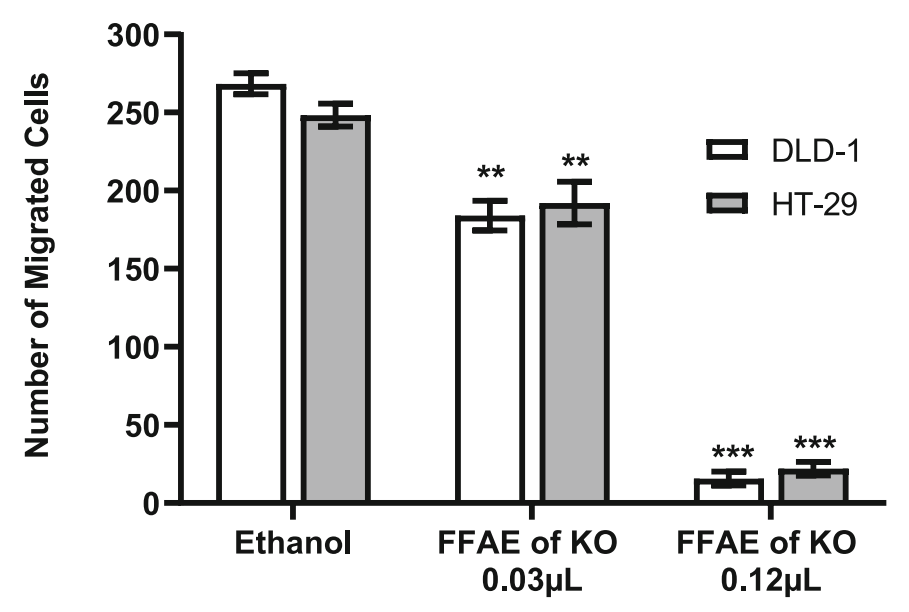

Treatment

Fig. 2 Effects of FFAE of krill oil on the viability of CRC cells

Panels b' and c', HT-29 cells treated with FFAE of krill oil at the concentrations of $0.03 \mu \mathrm{L} / 100 \mu \mathrm{L}$ and $0.12 \mu \mathrm{L} /$ $100 \mu \mathrm{L}$ respectively. Scale bar $=100 \mu \mathrm{M}$. (B) The number of migrated cells were quantified using the Boyden chamber assay. All treatments were performed in triplicate and repeated three times. Data are expressed as mean \pm SEM. $* * p<0.01$ and $* * * p<0.001$ indicate a significant difference between the treatment of krill oil extract and ethanol (vehicle) control.

Apoptosis of DLD-1 (A) and HT-29 (B) cells were determined using Annexin V/PI staining and detected by the flow cytometry following $8 \mathrm{~h}$ of treatment with FFAE of krill oil at $0.12 \mu \mathrm{L} / 100 \mu \mathrm{L}$. Panels (A') and (B') show the percentage of live, apoptotic and necrotic cells compared with the ethanol vehicle control after treatments. All treatments were performed in duplicate and the experiment was repeated three times. Data are expressed as mean \pm SEM. ${ }^{* * *} p<0.01$ and $\approx p<0.001$ indicate a significant difference between the treatment of krill oil extract and ethanol (vehicle) control.
Figures 4 and 5 show the effects of krill oil extract and cetuximab treatments on the expression of EGFR and pEGFR after the stimulation by EGF. DLD-1 cells treated by FFAE of krill oil at the concentrations of $0.03 \mu \mathrm{L} /$ $100 \mu \mathrm{L}$ and $0.12 \mu \mathrm{L} / 100 \mu \mathrm{L}$, and cetuximab at $20 \mu \mathrm{g} / \mathrm{mL}$ have shown a reduction in EGFR expression by 21.4, 27.9 and $29.9 \%$ respectively after treatment for $8 \mathrm{~h}$ compared to ethanol vehicle control (Fig. 4A'). A similar decrease in EGFR expression by $23.7,31.8$ and $29.9 \%$ was observed in HT-29 cells following treatments with FFAE of krill oil and cetuximab at the same concentrations for $8 \mathrm{~h}$ respectively compared to ethanol control (Fig. 5A'). Same treatments for DLD-1 cells have reduced pEGFR expression by $3.9,49.0$ and $56.6 \%$ respectively compared to the ethanol vehicle control (Fig. 4B'). Similarly, in HT-29 cells, reduced pEGFR levels by 36.7, 61.2 and $73.6 \%$ were also observed after $8 \mathrm{~h}$ of the same treatments compared to the ethanol vehicle control (Fig. $\left.5 B^{\prime}\right)$. These data were further supported by the 


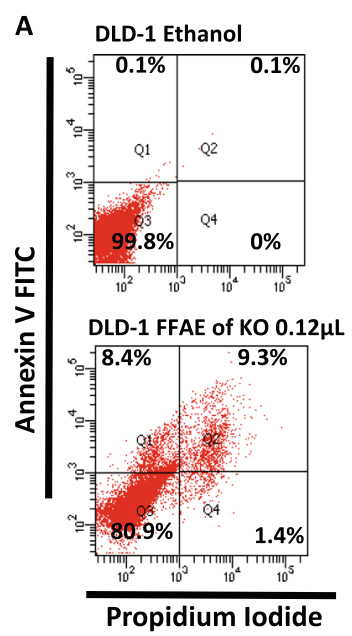

$A^{\prime}$

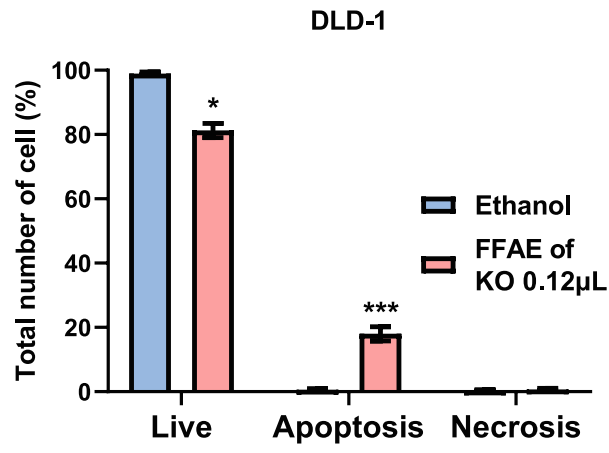

B

B' $^{\prime}$
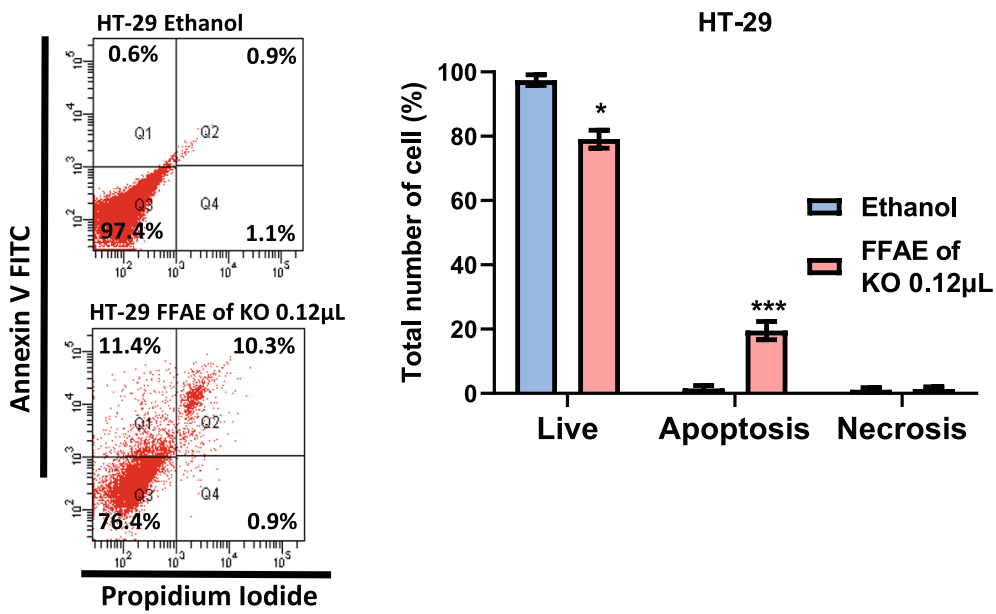

Fig. 3 Quantification of apoptosis following the treatment with FFAE of krill oil

immunohistochemistry assay results shown in Figs. 4 and 5 (A"and B"). The FFAE of krill oil has effectively inhibited the levels of EGFR and pEGFR in both cell lines in a dose-dependent manner. The immunohistochemistry results are consistent with western blot results in both cell lines following the treatments with FFAE of krill oil at $0.12 \mu \mathrm{L} / 100 \mu \mathrm{L}$ and cetuximab at $20 \mu \mathrm{g} / \mathrm{mL}$ for $8 \mathrm{~h}$.

The expression of EGFR (A) and pEGFR (B) in DLD-1 cells was determined using confocal microscopy. The expression of EGFR (A') and pEGFR (B') in DLD-1 cells was measured by western blotting following $8 \mathrm{~h}$ of treatment with FFAE of krill oil at $0.03 \mu \mathrm{L} / 100 \mu \mathrm{L}$ and $0.12 \mu \mathrm{L} / 100 \mu \mathrm{L}$, and Cetuximab (positive control) at $20 \mu \mathrm{g} / \mathrm{mL}$. Fluorescent intensity of EGFR (A") and pEGFR (B") expression in DLD-1 cells was determined using a monoclonal antibody for EGFR and pEGFR following $8 \mathrm{~h}$ of treatment with FFAE of krill oil at $0.12 \mu \mathrm{L} / 100 \mu \mathrm{L}$ and Cetuximab at $20 \mu \mathrm{g} / \mathrm{mL}$. Scale bar $=$ $50 \mu \mathrm{M}$. Magnification $=60 \mathrm{X}$. The treatments were performed in triplicate and the results were verified through at least three individual experiments. Data are expressed as mean \pm SEM. ${ }^{* * * *} p<0.001$ compared to ethanol (vehicle) control.

The expression of EGFR (A) and pEGFR (B) in HT-29 cells was determined using confocal microscopy. The expression of EGFR (A') and pEGFR (B') in HT-29 cells was measured by western blotting following $8 \mathrm{~h}$ of treatment with FFAE of krill oil at $0.03 \mu \mathrm{L} / 100 \mu \mathrm{L}, 0.12 \mu \mathrm{L} /$ $100 \mu \mathrm{L}$ and Cetuximab at $20 \mu \mathrm{g} / \mathrm{mL}$. Fluorescent intensity of EGFR (A") and pEGFR (B") expression in HT-29 cells was determined using a monoclonal antibody for EGFR and pEGFR following $8 \mathrm{~h}$ of treatment with FFAE of krill oil at $0.12 \mu \mathrm{L} / 100 \mu \mathrm{L}$ and Cetuximab at $20 \mu \mathrm{g} /$ 


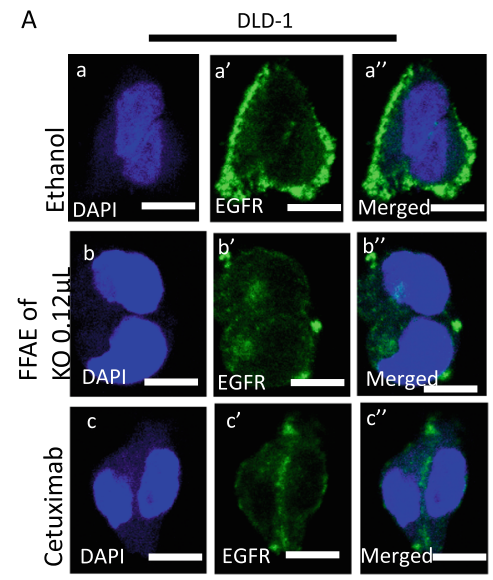

B

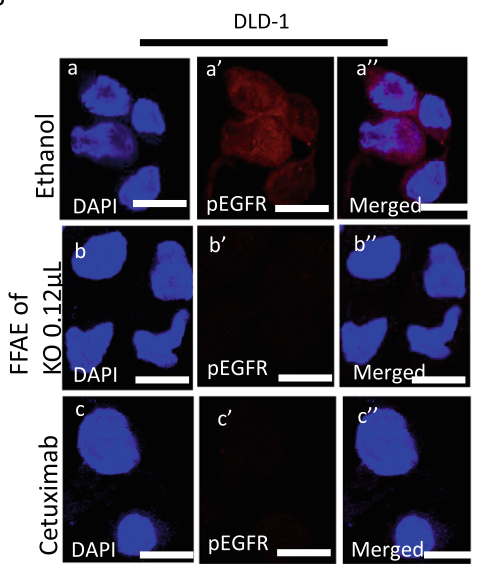

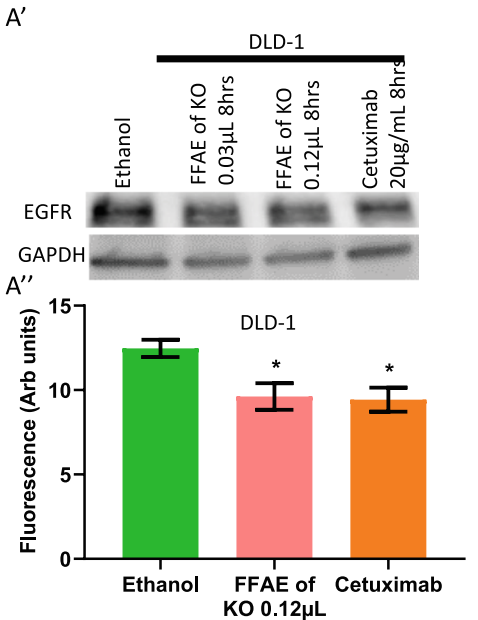

$\mathrm{B}^{\prime}$

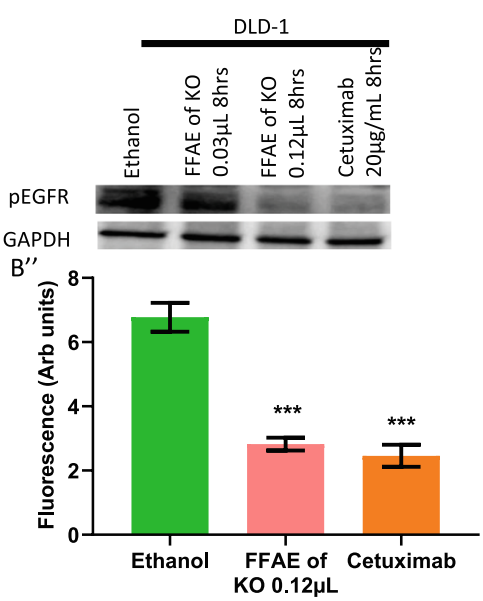

Fig. 4 Expression of EGFR and pEGFR in DLD-1 cells following the treatment with FFAE of krill oil

$\mathrm{mL}$. Scale bar $=50 \mu \mathrm{M}$. Magnification $=60 \mathrm{X}$. The treatments were performed in triplicate and the results were verified through at least three individual experiments. Data are expressed as mean \pm SEM. ${ }^{* * *} \mathrm{p}<0.001$ compared to ethanol (vehicle) control.

The FFAE of krill oil also reduced the level of pERK $1 / 2$ and $\mathrm{pAKT}$ proteins without altering the total protein levels of ERK1/2 and AKT in both DLD1 and HT-29 cells as shown in Figs. 6 and 7. DLD-1 cells treated by FFAE of krill oil at the concentrations of $0.03 \mu \mathrm{L} / 100 \mu \mathrm{L}$ and $0.12 \mu \mathrm{L} / 100 \mu \mathrm{L}$ for $8 \mathrm{~h}$ have shown a decrease in PERK $1 / 2$ protein expression by 22 and $72 \%$ respectively compared to ethanol vehicle control (Fig. 6A'). A similar reduction of pERK1/2 protein level by 24 and $73 \%$ was also observed in HT-29 cells following treatments with FFAE of krill oil at the same concentrations for $8 \mathrm{~h}$ respectively compared to the ethanol vehicle control (Fig. 6B').
These results were further verified by immunohistochemistry assay findings (Figs. 6A" and B").

The expression of pERK1/2 in DLD-1 (A) and HT-29 (B) cells was determined using confocal microscopy. The expression of pERK1/2 and total ERK1/2 in DLD-1 (A') and HT-29 (B') was measured by western blotting following $8 \mathrm{~h}$ of treatment with FFAE of krill oil at $0.03 \mu \mathrm{L} /$ $100 \mu \mathrm{L}$ and $0.12 \mu \mathrm{L} / 100 \mu \mathrm{L}$. Fluorescent intensity of pERK1/2 expression in DLD-1 (A") and HT-29 (B") cells was determined using a monoclonal antibody for pERK1/2 following $8 \mathrm{~h}$ of treatment with FFAE of krill oil at $0.12 \mu \mathrm{L} / 100 \mu \mathrm{L}$. Scale bar $=50 \mu \mathrm{M}$. Magnification $=$ $60 \mathrm{X}$. The treatments were performed in triplicate and the results were verified through at least three individual experiments. Data are expressed as mean \pm SEM. ${ }^{* * * *} p<$ 0.001 compared to ethanol (vehicle) control.

DLD-1 cells treated by FFAE of krill oil at $0.03 \mu \mathrm{L} /$ $100 \mu \mathrm{L}$ and $0.12 \mu \mathrm{L} / 100 \mu \mathrm{L}$ have also shown a reduction 

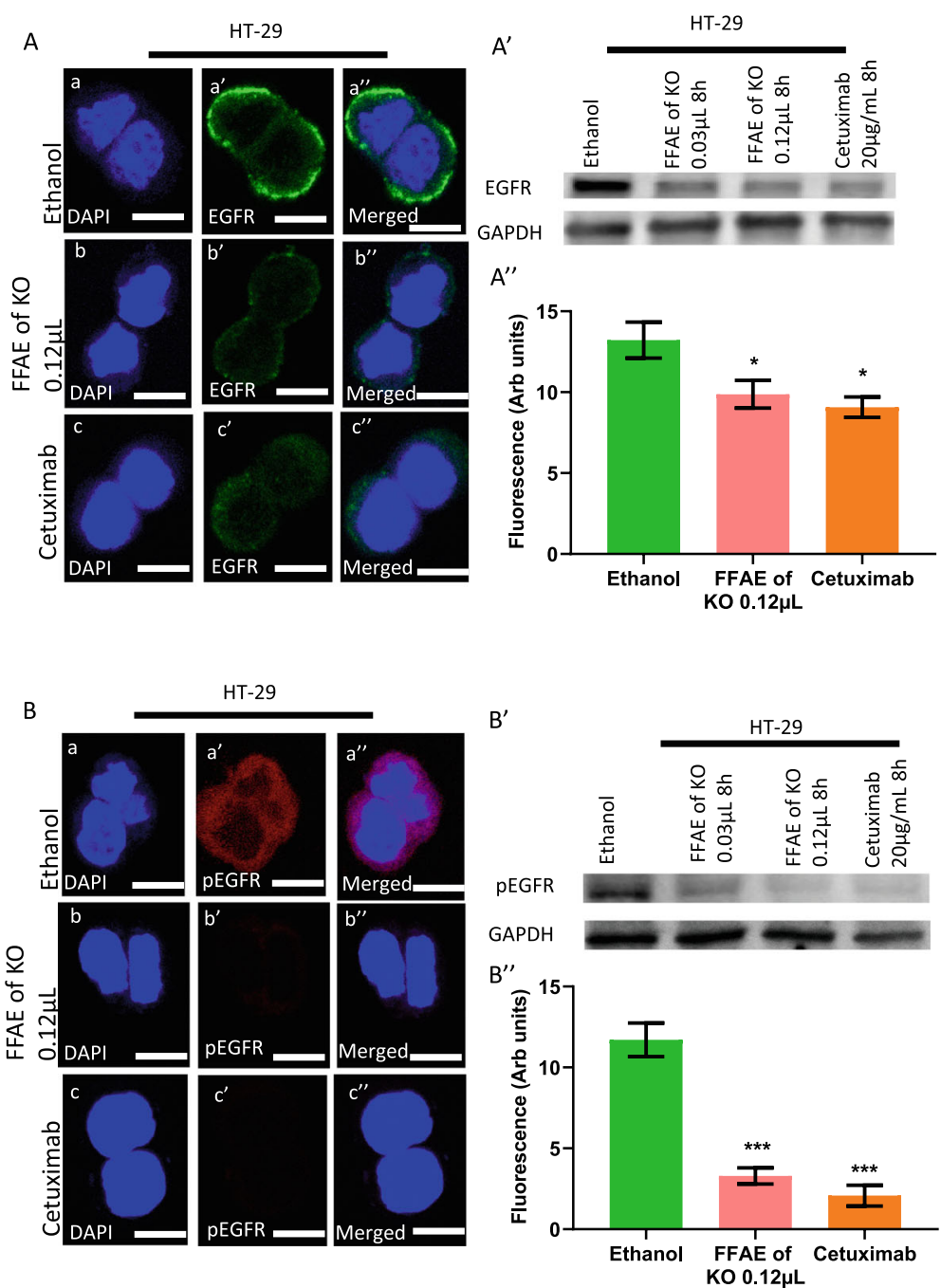

Fig. 5 Expression of EGFR and pEGFR in HT-29 cells following the treatment with FFAE of krill oil

of pAKT expression by 24.0 , and $48.5 \%$ respectively after $8 \mathrm{~h}$ of treatment with FFAE of krill oil compared to ethanol control (Fig. 7A'). The results from similar treatments for HT-29 cells have shown a decrease of pAKT protein levels by 25.4 and $38.4 \%$ respectively after $8 \mathrm{~h}$ of treatment (Fig. 7A'). These results are consistent with the observations from immunohistochemistry assay (Figs.7A"and B").

The expression of pAKT in DLD-1 (A) and HT-29 (B) cells was determined using confocal microscopy. The expression of pAKT and total AKT in DLD-1 (A') and HT-29 (B') cells was measured by western blotting following $8 \mathrm{~h}$ of treatment with FFAE of krill oil at $0.03 \mu \mathrm{L} /$ $100 \mu \mathrm{L}$ and $0.12 \mu \mathrm{L} / 100 \mu \mathrm{L}$. Fluorescent intensity of pAKT expression in DLD-1 (A") and HT-29 (B") cells was determined using a monoclonal antibody for $\mathrm{pAKT}$ following $8 \mathrm{~h}$ of treatment with FFAE of krill oil at $0.12 \mu \mathrm{L} / 100 \mu \mathrm{L}$. Scale bar $=50 \mu \mathrm{M}$. Magnification $=60 \mathrm{X}$. The treatments were performed in triplicate and the results were verified through at least three individual experiments. Data are expressed as mean \pm SEM. ${ }^{* * *} p<$ 0.001 compared to ethanol (vehicle) control.

As shown in Fig. 8, the FFAE of krill oil has significantly reduced the PD-L1 expression in both DLD-1 and HT-29 cell lines after $8 \mathrm{~h}$ of the treatment. The DLD-1 cells treated with FFAE of krill oil at the concentrations of $0.03 \mu \mathrm{L} / 100 \mu \mathrm{L}$ and $0.12 \mu \mathrm{L} / 100 \mu \mathrm{L}$ showed a decrease in PD-L1 protein expression by 26 and $67 \%$ respectively after $8 \mathrm{~h}$ of the treatment compared to the ethanol vehicle control (Fig. 8A'). A similar effect was also observed in HT-29 cells with the reductions of 23 and $72 \%$ following 8-h treatment with FFAE of krill oil at concentrations of $0.03 \mu \mathrm{L} / 100 \mu \mathrm{L}$ and $0.12 \mu \mathrm{L} / 100 \mu \mathrm{L}$ respectively compared to the ethanol control (Fig. 8B'). The results of immunohistochemistry are consistent with the western blot results showing a significant decrease in the expression of PD-L1 in both DLD-1 and HT-29 cell lines 


\section{A}
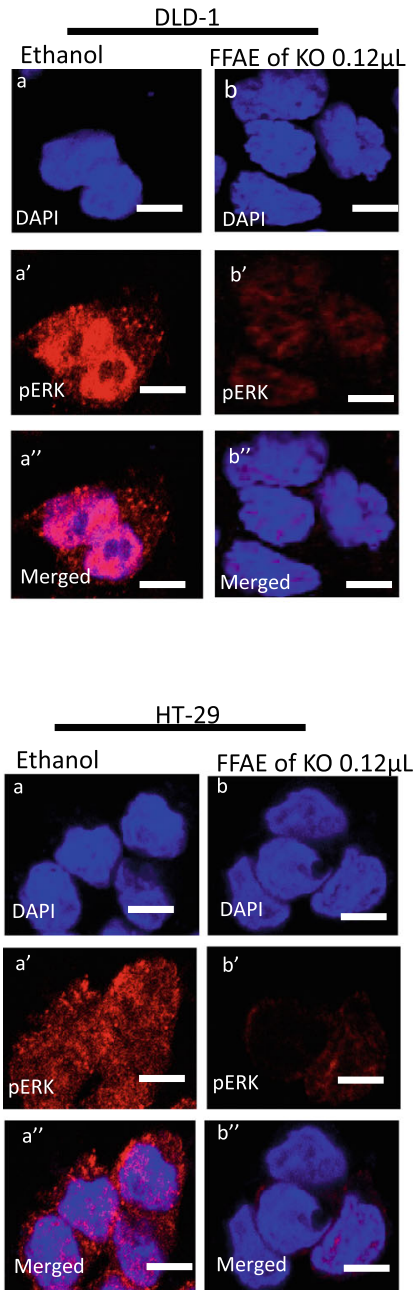

$A^{\prime}$
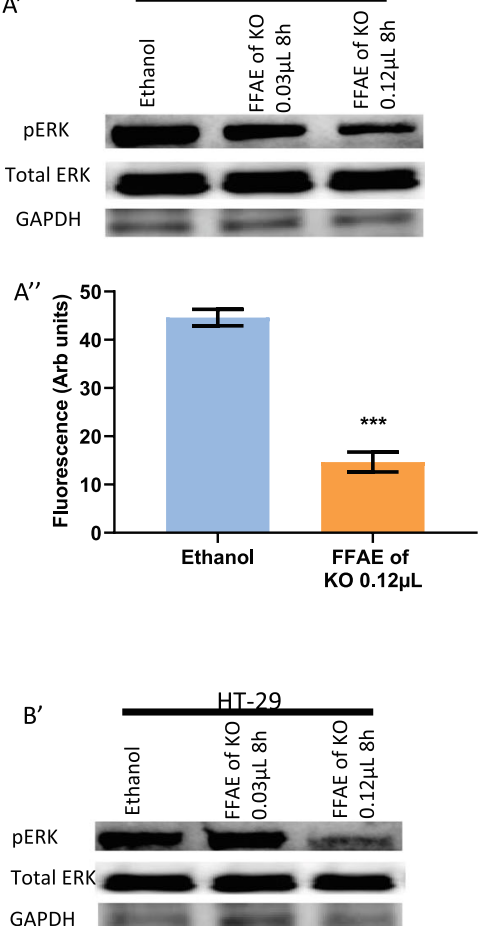

$B^{\prime \prime}$

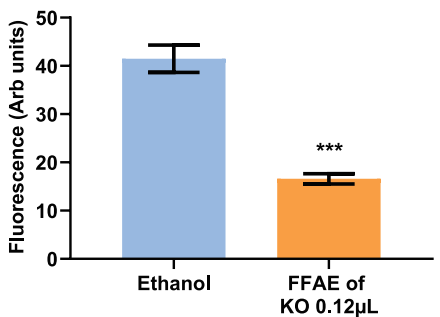

Fig. 6 Expression of pERK 1/ 2 in CRC cells following the treatment with FFAE of krill oil

compared to the ethanol vehicle control $(P<0.001)$ (Figs. 8A"and B").

The expression of PD-L1 in DLD-1 (A) and HT-29 (B) cells was determined using confocal microscopy. The expression of PD-L1 in DLD-1 (A') and HT-29 (B') cells was measured by western blotting following $8 \mathrm{~h}$ of treatment with FFAE of krill oil at $0.03 \mu \mathrm{L} /$ $100 \mu \mathrm{L}$ and $0.12 \mu \mathrm{L} / 100 \mu \mathrm{L}$. Fluorescent intensity of PD-L1 expression in DLD-1 (A") and HT-29 (B") cells was determined using a monoclonal antibody for PDL1 following $8 \mathrm{~h}$ of treatment with FFAE of krill oil at $0.12 \mu \mathrm{L} / 100 \mu \mathrm{L}$. Scale bar $=50 \mu \mathrm{M}$. Magnification $=$ $60 \mathrm{X}$. The treatments were performed in triplicate and the results were verified through at least three individual experiments. Data are expressed as mean \pm SEM. *** $p<0.001$ compared to ethanol (vehicle) control.

\section{Discussion}

This study demonstrated that the FFAE of krill oil inhibits the migration of human DLD-1 and HT-29 CRC cells. We also found that krill oil extract suppresses significantly the expression of EGFR, pEGFR and its downstream signalling, pERK $1 / 2$ and $\mathrm{pAKT}$. In addition, the expression of PD-L1 was reduced remarkably following the treatment with krill oil extract. The validation analysis confirmed the pro-apoptotic properties of krill oil as we previously reported using other techniques and different CRC cell lines [18].

The positive impacts of krill oil extract observed in this study are more likely attributed to its bioactive constituents, LC n-3 PUFA, mainly EPA and DHA. Limited studies by our group and others have shown the inhibitory effects of FFAE of krill oil on the growth and proliferation of human osteosarcoma and CRC cells and those 


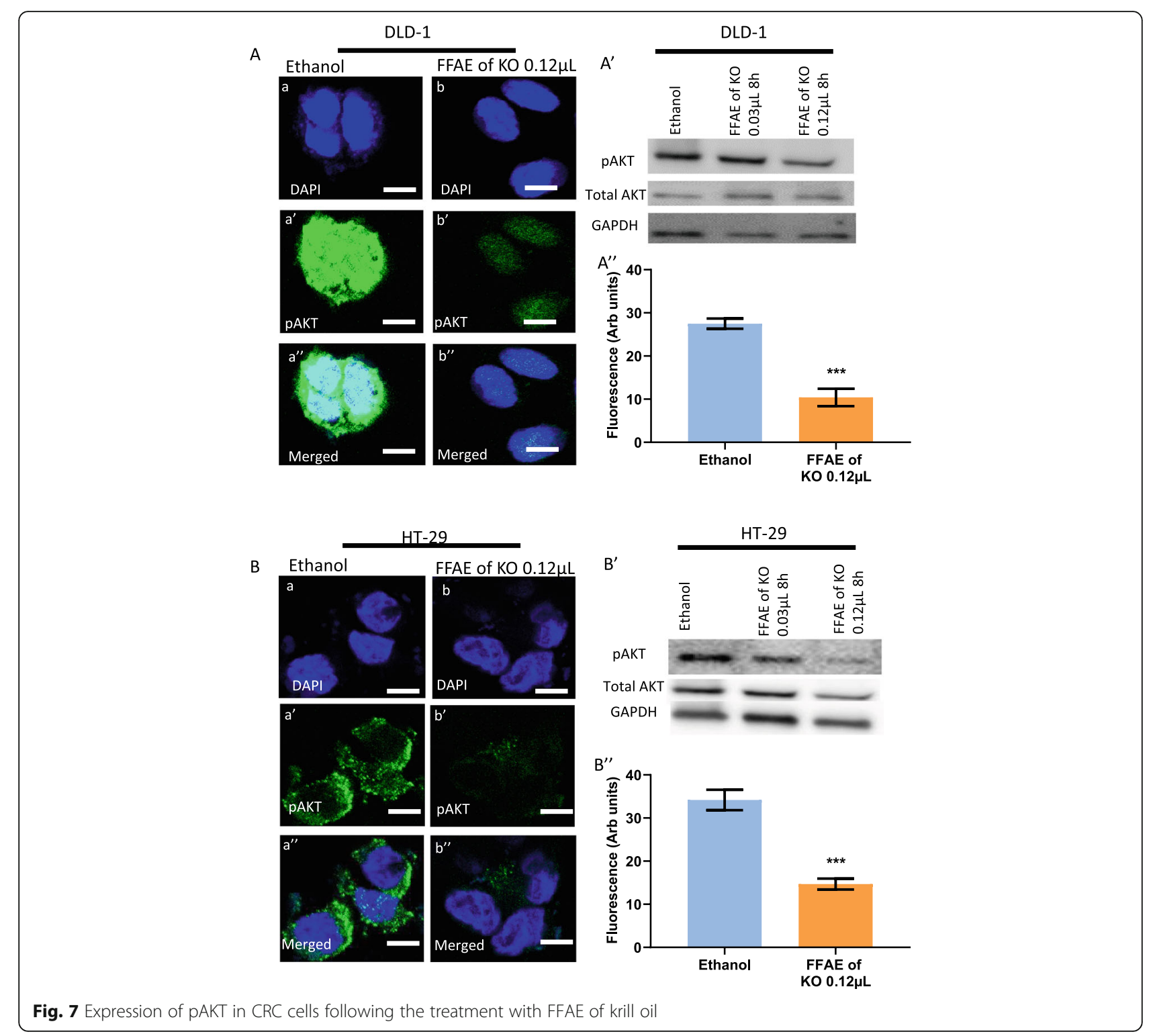

positive effects of krill oil were related to EPA and DHA $[29,30]$. In addition, we have observed the antimigratory effects of EPA and DHA on osteosarcoma cells [17]. Study by Zheng et al. has also found that DHA extracted from Antarctic krill inhibits the migration and invasion of breast cancer cells [31]. Previous in vitro and in vivo studies have reported the impacts of EPA and DHA, alone or in combination, on CRC suppression [32-34]. Several molecular mechanisms have also been proposed in relation to the role of $\mathrm{LC} n-3$ PUFA in CRC inhibition including the modulation of cell membrane composition and structure [35], induction of anti-inflammatory response [12, 36], promotion of apoptosis via activation of caspases [37-39], as well as alteration of receptor binding and signal transduction process $[37,40]$. A few studies have also shown the suppressive effects of LC n-3 PUFA on EGFR and the downstream signalling ERK and AKT pathways in CRC $[41,42]$. However, there has been no report available on the effect of krill oil on EGFR signalling. Moreover, no data have shown the association of either krill oil or LC n-3 PUFA and PD-L1 expression.

EGFR signalling pathway is a complex and tightly controlled process in normal cells. Disruption of this system contributes to malignant transformation and formation of tumour through cell proliferation, prolonged survival, invasion and metastasis [22, 43]. The present study has demonstrated a significant decrease in the expression of both EGFR and pEGFR in CRC cells following the treatment with FFAE of krill oil. Furthermore, the suppressive effect of krill oil extract on EGFR and pEGFR is comparable with Cetuximab, a monoclonal antibody that 


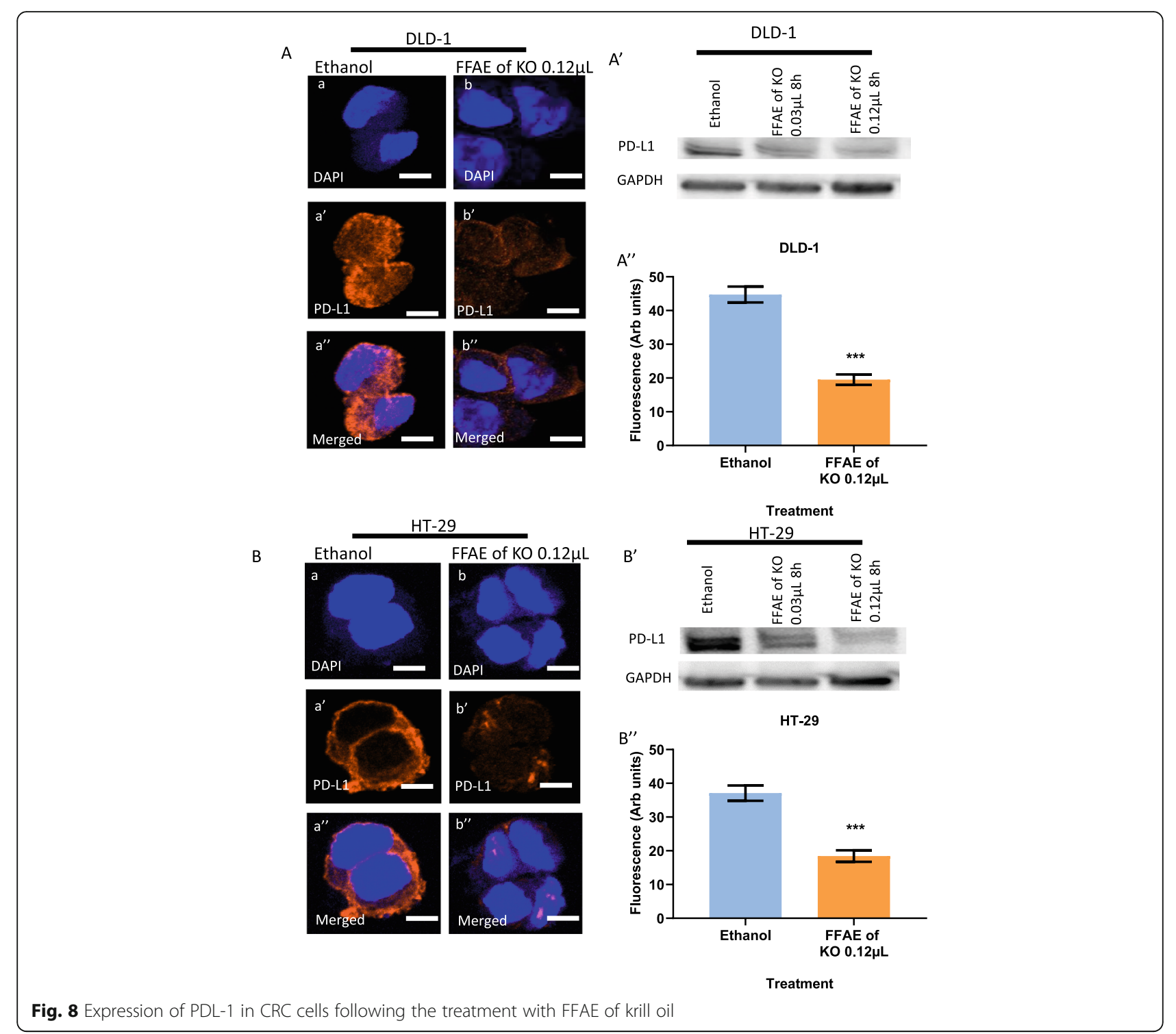

binds to the EGFR extracellular domain and deactivates the EGFR receptor to inhibit tumour cell growth [44]. This suggests the potential clinical benefits of krill oil although further in vivo studies are warranted. The available data have shown that EPA and DHA play a role in modulating the EGFR signalling pathway in CRC cells. Turk et al. [42] have reported that EPA and DHA exert their antiproliferative effect through the inhibition of EGFR in YAMC CRC cells associated with the alteration of membrane composition, fluidity and permeability. Changes in membrane property disturb the membrane raft formation resulting in the displacement of several raft-associated oncoproteins. It has been reported that the alterations in the lipid raft of cell membrane modify the localisation, suppression and activation of EGFR, as well as its downstream pathways in vitro and in vivo [32, 42]. Furthermore, a study on CRC HCT116 cells demonstrated that monoglyceride EPA (MAG-EPA) promotes apoptosis and inhibits tumour growth by suppression of the EGFR activation pathway [10]. A similar effect of LC n-3 PUFA has also been observed in MDA-MB-231 breast cancer cells. The alteration of lipid raft and reduction of EGFR level in these cells were found to be directly related to the inhibition of cell growth and the induction of cell apoptosis [45].

ERK1 and ERK2 are related protein-serine/threonine kinases involved in the Ras-Raf-MEK-ERK signal transduction cascade [46]. This cascade controls a large variety of processes including cell proliferation, differentiation, adhesion, migration, metabolism and transcription; and progression of cell cycle [23]. ERK1/2 is activated through 
the phosphorylation of tyrosine residues in ERK1 and ERK2 by phosphorylated MEK1/2 [46]. Phosphorylated ERK1/2 then translocates into the nucleus and regulates transcription factors leading to differential gene expression [47]. Several studies have shown that the activation of RAS/RAF/MEK/ERK pathways involves the promotion of CRC cell growth and proliferation [48]. The present study found that FFAE of krill oil reduces phosphorylated ERK1/2 expression in CRC cells in a dose-dependent manner. These results also correlate with the reduction of cell migration in both CRC cell lines tested in the study, suggesting the possible association between ERK signalling and anti-migratory property of krill oil extract (Fig. 9). Previous studies have also reported that EPA or DHA, alone or in combination, can reduce the phosphorylation of ERK1/2. Sun et al. [49] have observed that DHA treatment inhibits the phosphorylation of both MEK and ERK proteins and induces apoptosis in MCF-7 breast cancer cell line. Other studies have also reported that LC n-3 PUFA treatment decreases the phosphorylation of ERK1/2 in MIB-231 breast cancer cells [50]. Serini et al. [51] found that LC n-3 PUFA inhibits the phosphorylation of the MEK and ERK pathways.

The phosphoinositide 3-kinases (PI3Ks) are the family of lipid kinases that act as intermediate signalling molecules. These involve signal transduction from various growth factors and cytokines to induce the activation of multiple kinase pathways. One of the most well-known signalling pathways of PI3Ks is PI3K/AKT/mTOR [52, 53], and the phosphorylation of PI3Ks leads to the phosphorylation of AKT. The AKT signalling pathway plays a role in various normal cellular functions such as proliferation, growth, survival and migration. Furthermore, AKT is involved in protein synthesis, regulation of cell metabolism, DNA repair, apoptosis, angiogenesis and immune function $[52,54,55]$. It has been found that the dysfunction of PI3K/AKT signalling pathways is associated with the development of one-third of human cancers $[52,56,57]$ and resistance to anti-cancer therapies [58]. The activation of AKT signalling in cancer cells promotes cell survival and proliferation, prevents apoptosis, stops DNA repair, activates pro-angiogenic target genes and cell metastasis [59].

Our results indicate that the level of pAKT in CRC cells was significantly reduced following the treatment with FFAE of krill oil. This was correlated with a decrease in cell migration and an increase in apoptosis thus suggesting that the anti-cancer potential of krill oil may be related to the downregulation of AKT signalling pathway. Previous studies showed that EPA and DHA decrease AKT expression, reduce cell proliferation and inhibit the growth of A459 non-small lung cancer cell line [60], PC3 and DU145 prostate cancer cells [61], human pancreatic ductal epithelial [26], HCT116 colon cancer [10] and MCF-7 human breast cancer cells [62]. Moreover, a dis-localisation of EGFR and alteration of

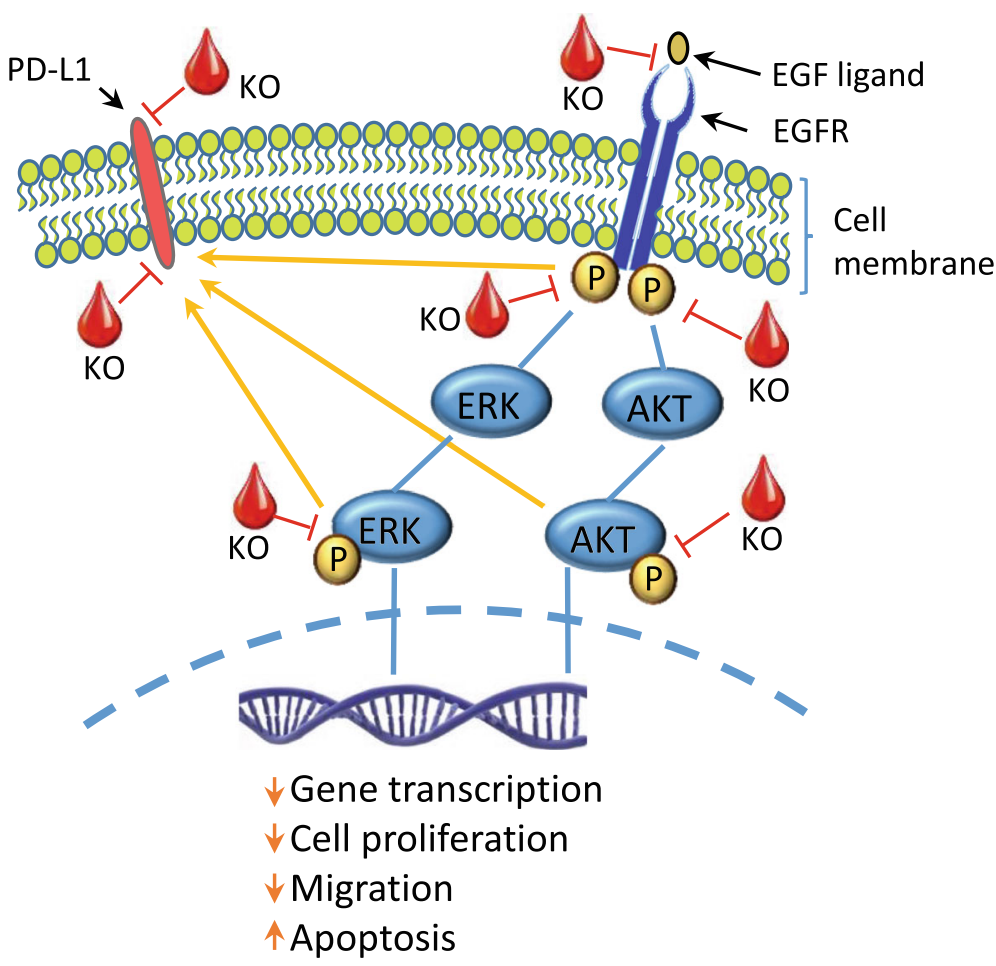

Fig. 9 Schematic summary of the modulation of EGFR signalling pathway by the FFAE of krill oil in CRC cells 
AKT signalling pathway that initiates the pro-apoptotic process were observed in human breast cancer cell lines MCF-7, T47D and MDA-MB-231 following the treatment of EPA and DHA [50].

Programmed death ligand (PD-L1) is a cell surface protein of the B7 family and a specific ligand for the programmed death-1 (PD-1) receptors expressed in the activated $\mathrm{T}$ cells $(\mathrm{CD} 4+$ and $\mathrm{CD} 8+)$ [63]. The high expression of PD-L1 is common in tumour cells. When PD-L1 binds to the corresponding receptor in $\mathrm{T}$ cells, it can strongly inhibit $\mathrm{T}$ cell activation and proliferation, and induces $\mathrm{T}$ cell apoptosis and then subsequently escapes immunosurveillance to promote further tumour growth [64-66]. Multiple signalling pathways regulate the PD-L1 expression. Some of the identified pathways are the hyper-activation of AKT-mTOR pathway $[58,67,68]$ and the activation of ERK/MAPK pathways $[67,69,70]$ resulting in the higher expression of PD-L1. Moreover, it has been reported that the activation of EGFR signalling pathway can up-regulate the expression of PD-L1 [71, 72]. The link between EGFR and activation of PD-L1 plays an important role in preventing cancer cells escaping the immune surveillance and, therefore the progression of cancer. This has been extensively studied in lung cancer cells and to some extent in lung cancer patients [73]. Limited studies on CRC cells showed that EGFR increases post-translational glycosylation and stability of PD-L1 [74]. It has been demonstrated that activation of EGFR mutation is associated with enhanced PD-L1 expression in human lung cancer cells which is reduced by EGFR inhibitors. Moreover, it was found that EGFR signalling regulates PDL1 expression via AKT, p-ERK1/2/p-c-Jun, and MAPK pathways [70, 75-77]. Taken together, the present results suggest that krill oil extract inhibits EGFR and pEGFR expression and the downstream pERK/ERK1/2 and pAKT/ AKT signalling which associates with reduction in PD-L1 expression. It implies that krill oil may have a potential in preventing cancer cells from escaping the immune surveillance. This interaction may have led to the inhibition of CRC cell migration (Fig. 9). Further investigation with EGFR knockout/knockdown cell lines is required to elucidate the mechanistic interplay between krill oil, EGFR and PD-L1.

The FFAE of krill oil inhibits the expression of EGFR and phosphorylated EGFR, its downstream signalling pathways of ERK1/2 and AKT, as well as PD-L1. These changes result in a suppressed proliferation, migration and promoted apoptosis of cancer cells. KO: free fatty acid extracted of krill oil.

\section{Conclusions}

Our findings demonstrated that FFAE of krill oil reduces the migration of CRC cells. The health-benefitting effects of krill oil extract on CRC cells may be associated with the downregulation of EGFR and its downstream signalling pathways of ERK $1 / 2$ and AKT. Furthermore, the FFAE of krill oil suppressed the expression of PD-L1 and thereby suggests it may have a potential in preventing cancer cells escape from immunosurveillance. These results indicate that krill oil may be a useful alternative complementary therapy for CRC. Further in vivo studies are required to validate these findings.

\begin{abstract}
Abbreviations
CRC: Colorectal cancer; FFAE: Free fatty acid extract; EPA: Eicosapentaenoic acid; DHA: Docosahexaenoic acid; PUFA: Polyunsaturated fatty acids; LC n-3 PUFA: Long chain n-3 PUFA; FFAE of KO: Free fatty acids extractions of krill oil; EGFR: Epidermal growth factor receptor; pEGFR: Phosphoralated EGFR; PD-L1: Programmed death ligand-1; PI3K: Phosphoinositide 3-kinase; AKT: Protein kinase B; mTOR: Mammalian target of rapamycin; PAKT: Phosphoralated AKT; MAPK: Miotogen activated protein kinase; ERK: Extracellular signal regulated kinase; pERK: Phosphoralated ERK; STAT3: Signal transducer and activator of transcription 3; PI: Propidium iodide; AVBB: Annexin V binding buffer; ATCC: American Tissue Culture Collection; FCS: Foetal calf serum; HEPES: 4-2- hydroxyethyl - 1-

piperazineethanesulfonic; PBS: Phosphate buffered saline; PBS-T: Phosphate buffered saline + Tween 20; SD: Standard deviation; SEM: Standard error of mean; DAPI: 4,6-diamidino-2-phenylindole.; RIPA: Radioimmunoprecipitation assay buffer; SDS: Sodium dodecyl sulphate; GAPDH: Glyceraldehydes-3phosphate de-hydrogenase
\end{abstract}

\section{Acknowledgments}

Not applicable.

\section{Authors' contributions}

$\mathrm{XS}, \mathrm{KN}, \mathrm{RL}$ and AJ designed the study. AJ collected and analysed the data and drafted the manuscript. MV assisted with FACS and confocal microscopy, data collection and manuscript editing. XS, KN and RL are responsible for data interpretation and contributed to critical revision of the manuscript. All authors read and approved the final manuscript.

\section{Funding}

Not applicable.

\section{Availability of data and materials}

The datasets from the present study are available from the corresponding author upon request.

Ethics approval and consent to participate

Not applicable.

\section{Consent for publication}

Not applicable.

\section{Competing interests}

The authors declare that they have no competing interest.

\section{Author details}

${ }^{1}$ Institute for Health and Sport, Victoria University, P.O. Box 14428, Melbourne, Vic 8001, Australia. ${ }^{2}$ Department of Surgery, The Royal Melbourne Hospital, The University of Melbourne, Parkville, Australia. ${ }^{3}$ Department of Medicine, Western Health, The University of Melbourne, Melbourne, Australia.

${ }^{4}$ Regenerative Medicine and Stem Cell Program, Australian Institute for Muscular Skeletal Science (AIMSS), Melbourne, Australia.

Received: 10 July 2020 Accepted: 17 November 2020 Published online: 07 December 2020

\section{References}

1. The American Cancer Society. Cancer Facts \& Figures 2014 http://www. cancer.org/research/cancerfactsstatistics/cancerfactsfigures 2014/2014.

2. Arnold M, Sierra MS, Laversanne M, Soerjomataram I, Jemal A, Bray F. Global patterns and trends in colorectal cancer incidence and mortality. Gut. 2017: 66(4):683-91. 
3. World Health Organisation. Cancer 2018 https:/www.who.int/health-topics/ cancer\#tab=tab_1.

4. Binefa G, Rodriguez-Moranta F, Teule A, Medina-Hayas M. Colorectal cancer: from prevention to personalized medicine. World J Gastroenterol. 2014; 20(22):6786-808

5. Brouwer NPM, Bos A, Lemmens V, Tanis PJ, Hugen N, Nagtegaal ID, De Wilt JHW, Verhoeven RHA. An overview of 25 years of incidence, treatment and outcome of colorectal cancer patients. Int J Cancer. 2018;143(11):2758-66.

6. Inada R, Nagasaka T, Watanabe A, Yagi T, Mori Y, Kondo Y, Kishimoto H, Umeda Y, Fujiwara T. Comparison of outcomes between symptomatic and asymptomatic patients with colorectal cancer: a propensity score-matched analysis of surgical invasiveness, medical costs and oncological outcomes. BMJ Open Gastroenterol. 2017:4(1):e000146.

7. Van der Jeught $K, X u H C$, Li YJ, Lu XB, Ji G. Drug resistance and new therapies in colorectal cancer. World J Gastroenterol. 2018;24(34):3834-48.

8. Nurgali K, Jagoe RT, Abalo R. Editorial: adverse effects of Cancer chemotherapy: anything new to improve tolerance and reduce Sequelae? Front Pharmacol. 2018;9:245.

9. Volpato M, Hull MA. Omega-3 polyunsaturated fatty acids as adjuvant therapy of colorectal cancer. Cancer Metastasis Rev. 2018;37(2-3):545-55.

10. Morin-Ben SHV. Epidermal Growth Factor Receptor Tyrosine Kinase Inhibiters in Treatment of Metastatic Non-Small Cell Lung Cancer,with a Focus on Afatinib. Front Oncol. 2017;7:97.

11. Fluckiger A, Dumont A, Derangere V, Rebe C, de Rosny C, Causse S. Inhibition of colon cancer growth by docosahexaenoic acid involves autocrine production of TNFalpha. Oncogene. 2016;35(35):4611-22.

12. Miccadei S, Masella R, Mileo AM, Gessani S. Omega3 Polyunsaturated Fatty Acids as Immunomodulators in Colorectal Cancer: New Potential Role in Adjuvant Therapies. Frontiers Immunol. 2016;7:486.

13. Tou JC, Jaczynski J, Chen YC. Krill for human consumption: nutritional value and potential health benefits. Nutr Rev. 2007;65(2):63-77.

14. Winther B, Hoem N, Berge K, Reubsaet L. Elucidation of phosphatidylcholine composition in krill oil extracted from Euphausia superba. Lipids. 2011;46(1): 25-36.

15. Sung HH, Sinclair AJ, Lewandowski PA, Su XQ. Postprandial long-chain $n-3$ polyunsaturated fatty acid response to krill oil and fish oil consumption in healthy women: a randomised controlled, single-dose, crossover study. Asia Pac J Clin Nutr. 2018;27(1):148-57.

16. Ulven SM, Kirkhus B, Lamglait A, Basu S, Elind E, Haider T, Berge K, Vic H, Pedersen Jl. Metabolic effects of krill oil are essentially similar to those of fish oil but at lower dose of EPA and DHA, in healthy volunteers. Lipids. 2011;46(1):37-46

17. Su XU, Tanalgo P, Bustos M, Dass CR. The effect of krill oil and $n-3$ polyunsaturated fatty acids on human osteosarcoma cell proliferation and migration. Curr Drug Targets. 2018;19(5):479-86.

18. Jayathilake AG, Senior PV, Su XQ. Krill oil extract suppresses cell growth and induces apoptosis of human colorectal cancer cells. BMC Complement Altern Med. 2016;16(1):328.

19. Jayathilake AG, Kadife E, Luwor RB, Nurgali K, Su XQ. Krill oil extract suppresses the proliferation of colorectal cancer cells through activation of caspase 3/9. Nutr Metab (Lond). 2019;16:53.

20. Zhu JJ, Shi JH, Qian WB, Cai ZZ, Li D. Effects of krill oil on serum lipids of hyperlipidemic rats and human SW480 cells. Lipids Health Dis. 2008;7:30

21. Voldborg BR, Damstrup L, Spang-Thomsen M, Poulsen HS. Epidermal growth factor receptor (EGFR) and EGFR mutations, function and possible role in clinical trials. Ann Oncol. 1997:8(12):1197-206.

22. Sasaki T, Hiroki K, Yamashita Y. The role of epidermal growth factor receptor in cancer metastasis and microenvironment. Biomed Res Int. 2013;2013: 546318.

23. Roberts RB, Min L, Washington MK, Olsen SJ, Settle SH, Coffey RJ, Threadgill DW. Importance of epidermal growth factor receptor signaling in establishment of adenomas and maintenance of carcinomas during intestinal tumorigenesis. Proc Natl Acad Sci U S A. 2002;99(3):1521-6.

24. Crane CA, Panner A, Murray JC, Wilson SP, Xu H, Chen L, Simko JP, Waldman FM, Pieper RO, Parsa AT. PI(3) kinase is associated with a mechanism of immunoresistance in breast and prostate cancer. Oncogene. 2009;28(2):306-12.

25. Parsa AT, Waldron JS, Panner A, Crane CA, Parney IF, Barry JJ, Cachola KE, Murray JC, Tihan T, Jensen MC, Mischel PS, Stokoe D, Pieper RO. Loss of tumor suppressor PTEN function increases B7-H1 expression and immunoresistance in glioma. Nat Med. 2007;13(1):84-8.
26. Ding Y, Mullapudi B, Torres C, Mascarinas E, Mancinelli G, Diaz AM, McKinney R, Barron M, Schultz M, Heiferman M, Wojtanek M, Adraian K, DeCant B, Rao S, Ouellette M, Taso MS, Bentrem DJ, Grippo PJ. Omega-3 fatty acids prevent early pancreatic carcinogenesis via repression of the AKT pathway. Nutrients. 2018;10(9):1289. https://doi.org/10.3390/nu10091289.

27. Escors DG-CM, Zuazo M, Arasanz H, Garcia-Granda MJ, Vera R, Kochan G The intracellular signalosome of PD-L1 in cancer cells. Signal transcuct Target Therap. 2018;3:26. https://doi.org/10.1038/s41392-018-0022-9.

28. Salimon J, Abdullah BM, Salih N. Hydrolysis optimization and characterization study of preparing fatty acids from Jatropha curcas seed oil. Chem Cent J. 2011;5:67.

29. Xie DGM, Wei W, Jin J, Wang X, Wang $X$, Jin Q. Antarctic krill (Euphausia superba) oil: a comprehensive review of chemical composition, extraction technologies, health benefits, and current application. Compr Rev Food Sci Food Saf. 2019;18(2):514-34.

30. Zheng W, Wang X, Cao W, Yang B, Mu Y, Dong Y. E-configuration structures of EPA and DHA derived from Euphausia superba and their significant inhibitive effects on growth of human cancer cell lines in vitro. Prostaglandins Leukot Essent Fatty Acids. 2017:117:47-53.

31. Zheng W, Li J, Wang X, Yuan Y, Zhang J, Xiu Z. Effects of Antarctic krill docosahexaenoic acid on MCF-7 cell migration and invasion induced by the interaction of CD95 with caveolin-1. Life Sci. 2018;192:270-7.

32. Lee JY, Sim TB, Lee JE, Na HK. Chemopreventive and chemotherapeutic effects of fish oil derived Omega-3 polyunsaturated fatty acids on Colon carcinogenesis. Clinical nutrition research. 2017;6(3):147-60.

33. Eltweri AM, Thomas AL, Metcalfe M, Calder PC, Dennison AR, Bowrey DJ. Potential applications of fish oils rich in omega-3 polyunsaturated fatty acids in the management of gastrointestinal cancer. Clin Nutr. 2016;36(1):65-78.

34. Park JM, Kwon SH, Han YM, Hahm KB, Kim EH. Omega-3 polyunsaturated fatty acids as potential chemopreventive agent for gastrointestinal cancer. J Cancer Prevention. 2013;18(3):201-8.

35. Fuentes NR, Salinas ML, Kim E, Chapkin RS. Emerging role of chemoprotective agents in the dynamic shaping of plasma membrane organization. Biochim Biophys Acta Biomembr. 2017;1859(9 Pt B):1668-78.

36. Michalak A, Mosinska P, Fichna J. Polyunsaturated fatty acids and their derivatives: therapeutic value for inflammatory, functional gastrointestinal disorders, and colorectal Cancer. Front Pharmacol. 2016;7:459.

37. D'Eliseo D, Velotti F. Omega-3 fatty acids and cancer cell cytotoxicity: implications for multi-targeted cancer therapy. J Clin Med. 2016;5(2):15. https://doi.org/10.3390/jcm5020015.

38. Zhang C, Yu H, Ni X, Shen S, Das UN. Growth inhibitory effect of polyunsaturated fatty acids (PUFAs) on colon cancer cells via their growth inhibitory metabolites and fatty acid composition changes. PLoS One. 2015;10(4):e0123256.

39. Giros A, Grzybowski M, Sohn VR, Pons E, Fernandez-Morales J, Xicola RM, Sethi P, Grzybowski J, Goel A, Boland CR, Gassull MA, Llor X. Regulation of colorectal cancer cell apoptosis by the $n-3$ polyunsaturated fatty acids Docosahexaenoic and Eicosapentaenoic. Cancer Prev Res (Phila). 2009;2(8):732-42.

40. Cockbain AJ, Toogood GJ, Hull MA. Omega-3 polyunsaturated fatty acids for the treatment and prevention of colorectal cancer. Gut. 2012;61(1):135-49.

41. Rogers KR, Kikawa KD, Mouradian M, Hernandez K, McKinnon KM, Ahwah SM, Pardini RS. Docosahexaenoic acid alters epidermal growth factor receptor-related signaling by disrupting its lipid raft association. Carcinogenesis. 2010;31(9):1523-30.

42. Turk HF, Chapkin RS. Membrane lipid raft organization is uniquely modified by $n-3$ polyunsaturated fatty acids. Prostaglandins Leukot Essent Fatty Acids. 2013;88(1):43-7.

43. Matucci-Cerinic M, Casini A. Ketoprofen vs etofenamate in a controlled double-blind study: evidence of topical effectiveness in soft tissue rheumatic pain. Int J Clin Pharmacol Res. 1988;8(3):157-60.

44. Jonker DJ, O'Callaghan CJ, Karapetis CS, Zalcberg JR, Tu D, Au HJ, Berry R, Krahn M, Price T, Simes RJ, Tebbutt NC, van Hazel G, Wierzbicki R, Langer C, Moore MJ. Cetuximab for the treatment of colorectal cancer. N Engl J Med. 2007;357(20):2040-8.

45. Schley PD, Jijon HB, Robinson LE, Field CJ. Mechanisms of omega-3 fatty acid-induced growth inhibition in MDA-MB-231 human breast cancer cells. Breast Cancer Res Treat. 2005;92(2):187-95.

46. Mebratu Y, Tesfaigzi Y. How ERK1/2 activation controls cell proliferation and cell death: is subcellular localization the answer? Cell Cycle. 2009:8(8):1168-75.

47. Zhang Z, Zhou X, Shen H, Wang D, Wang Y. Phosphorylated ERK is a potential predictor of sensitivity to sorafenib when treating hepatocellular carcinoma: evidence from an in vitro study. BMC Med. 2009;7:41. 
48. Millington GW. Mutations of the BRAF gene in human cancer, by Davies et al. (nature 2002; 417: 949-54). Clin Exp Dermatol. 2013;38(2):222-3.

49. Sun H, Hu Y, Gu Z, Owens RT, Chen YQ, Edwards IJ. Omega-3 fatty acids induce apoptosis in human breast cancer cells and mouse mammary tissue through syndecan-1 inhibition of the MEK-Erk pathway. Carcinogenesis. 2011:32(10):1518-24

50. Cao W, Ma Z, Rasenick MM, Yeh S, Yu J. N-3 poly-unsaturated fatty acids shift estrogen signaling to inhibit human breast cancer cell growth. PLoS One. 2012;7(12):e52838.

51. Serini S, Ottes Vasconcelos R, Fasano E, Calviello G. Epigenetic regulation of gene expression and M2 macrophage polarization as new potential omega3 polyunsaturated fatty acid targets in colon inflammation and cancer. Expert Opin Ther Targets. 2016;20(7):843-58.

52. Akinleye A, Avvaru P, Furqan M, Song Y, Liu D. Phosphatidylinositol 3-kinase (PI3K) inhibitors as cancer therapeutics. J Hematol Oncol. 2013;6(1):88.

53. Liu P, Cheng H, Roberts TM, Zhao JJ. Targeting the phosphoinositide 3kinase pathway in cancer. Nat Rev Drug Discov. 2009;8(8):627-44.

54. Szymonowicz K, Oeck S, Malewicz NM, Jendrossek V. New insights into protein kinase b/akt signaling: role of localized akt activation and compartment-specific target proteins for the cellular radiation response. Cancers. 2018;10(3):78.

55. Henderson V, Smith B, Burton LJ, Randle D, Morris M, Odero-Marah VA. Snail promotes cell migration through PI3K/AKT-dependent Rac1 activation as well as PI3K/AKT-independent pathways during prostate cancer progression. Cell Adhes Migr. 2015;9(4):255-64

56. Arteaga CL. Clinical development of phosphatidylinositol-3 kinase pathway inhibitors. Curr Top Microbiol Immunol. 2010;347:189-208.

57. Shaw R, Festing MF, Peers I, Furlong L. Use of factorial designs to optimize animal experiments and reduce animal use. ILAR J. 2002;43(4):223-32.

58. Yang J, Nie J, Ma X, Wei Y, Peng Y, Wei X. Targeting PI3K in cancer: mechanisms and advances in clinical trials. Mol Cancer. 2019;18(1):26.

59. Calvo E, Bolos V, Grande E. Multiple roles and therapeutic implications of Akt signaling in cancer. OncoTargets Therap. 2009;2:135-50.

60. Yin $Y$, Sui $C$, Meng F, Ma $P$, Jiang $Y$. The omega-3 polyunsaturated fatty acid docosahexaenoic acid inhibits proliferation and progression of non-small cell lung cancer cells through the reactive oxygen species-mediated inactivation of the PI3K /Akt pathway. Lipids Health Dis. 2017;16(1):87.

61. Shin S, Jing K, Jeong S, Kim N, Song KS, Heo JY, Park H, SeoK S, Han J, Park J, Kweon GR, Kiel Park S, Wu T, Hwang BD, Lim K. The omega-3 polyunsaturated fatty acid DHA induces simultaneous apoptosis and autophagy via mitochondrial ROS-mediated Akt-mTOR signaling in prostate cancer cells expressing mutant p53. BioMed Res Int. 2013;2013:568671.

62. Huang LH, Chung HY, Su HM. Docosahexaenoic acid reduces sterol regulatory element binding protein-1 and fatty acid synthase expression and inhibits cell proliferation by inhibiting pAkt signaling in a human breast cancer MCF-7 cell line. BMC Cancer. 2017;17(1):890.

63. Pardoll DM. The blockade of immune checkpoints in cancer immunotherapy. Nat Rev Cancer. 2012;12(4):252-64.

64. Sun C, Mezzadra R, Schumacher TN. Regulation and function of the PD-L1 checkpoint. Immunity. 2018;48(3):434-52.

65. Goldberg MV, Maris CH, Hipkiss EL, Flies AS, Zhen L, Tuder RM, Grosso JF, Harris TJ, Getnet D, Whartenby KA, Brockstedt DG, Dubensky TW, Chen L, Pardoll DM, Drake CG. Role of PD-1 and its ligand, B7-H1, in early fate decisions of CD8 T cells. Blood. 2007;110(1):186-92.

66. Zha Y, Blank C, Gajewski TF. Negative regulation of T-cell function by PD-1. Crit Rev Immunol. 2004;24(4):229-37.

67. Zerdes I, Matikas A, Bergh J, Rassidakis GZ, Foukakis T. Genetic, transcriptional and post-translational regulation of the programmed death protein ligand 1 in cancer: biology and clinical correlations. Oncogene. 2018;37(34):4639-61

68. Lastwika KJ, Wilson W, 3rd, Li QK, Norris J, Xu H, Ghazarian SR, Kitagawa H, Kawabata S, Taube JM,Yao S, Liu Ln, Gills JJ,Dennis PA. Control of PD-L1 Expression by Oncogenic Activation of the AKT-mTOR Pathway in NonSmall Cell Lung Cancer. Cancer Res 2016;76(2):227-238.

69. Bai J, Gao Z, Li X, Dong L, Han W, Nie J. Regulation of PD-1/PD-L1 pathway and resistance to PD-1/PD-L1 blockade. Oncotarget. 2017;8(66):110693-707.

70. Sumimoto H, Takano A, Teramoto K, Daigo Y. RAS-mitogen-activated protein kinase signal is required for enhanced PD-L1 expression in human lung cancers. PLoS One. 2016;11(11):e0166626.
71. Liang H, Liu X, Wang M. Immunotherapy combined with epidermal growth factor receptor-tyrosine kinase inhibitors in non-small-cell lung cancer treatment. Onco Targets Ther. 2018;11:6189-96.

72. Zhang N, Zeng Y, Du W, Zhu J, Shen D, Liu Z. Huang JA. The EGFR pathway is involved in the regulation of PD-L1 expression via the IL-6/JAK/STAT3 signaling pathway in EGFR-mutated non-small cell lung cancer. Int J Oncol. 2016:49(4):1360-8.

73. Sasada T, Azuma K, Ohtake J, Fujimoto Y. Immune responses to epidermal growth factor receptor (EGFR) and their application for Cancer treatment. Front Pharmacol. 2016;7:405

74. Yin X, Wang Y, Bai S, Feng W, Feng L, Zhao W, Wei M, Pang X, Liu S, Chen $H$, He F, Cheng Y, Yin J, Zhang D, Zheng J, Wang L, Fan X, Wan X. Epidermal growth factor receptor stabilizes programmed death ligand 1 by glycosylation in colorectal cancer with microstatellite instability status. J BioX Research. 2019:2(1):1-8.

75. Chen N, Fang W, Zhan J, Hong S, Tang Y, Kang S, Zhang Y, He X, Zhou T, Qin T, Huang Y, Yi X, Zhang L. Upregulation of PD-L1 by EGFR activation mediates the immune escape in EGFR-driven NSCLC: implication for optional immune targeted therapy for NSCLC patients with EGFR mutation. J Thorac Oncol. 2015:10(6):910-23.

76. Chen H-N, Liang K-H, Lai J-K, Lan C-H, Liao M-Y, Hung S-H, Chuang Y-T, Chen K-C, Wei-FuW T, Wu HC. EpCAM signaling promotes tumor progression and protein stability of PD-L1 through the EGFR pathway. Cancer Res. 2020:80(22):5035-50.

77. Fang W, Zhang J, Hong S, Zhan J, Chen N, Qin T, Tang Y, Zhang Y, Kang S, Zhou T, Wu X, Liang W, Hu Z, Ma Y, Zhao Y, Tian Y, Yang Y, Xue C, Yan Y, Hou $X$, Huang $P$, Huang $Y$, Zhao H, Zhang L. EBV-driven LMP1 and IFNgamma up-regulate PD-L1 in nasopharyngeal carcinoma: implications for oncotargeted therapy. Oncotarget. 2014;5(23):12189-202.

\section{Publisher's Note}

Springer Nature remains neutral with regard to jurisdictional claims in published maps and institutional affiliations.
Ready to submit your research? Choose BMC and benefit from:

- fast, convenient online submission

- thorough peer review by experienced researchers in your field

- rapid publication on acceptance

- support for research data, including large and complex data types

- gold Open Access which fosters wider collaboration and increased citations

- maximum visibility for your research: over $100 \mathrm{M}$ website views per year

At $\mathrm{BMC}$, research is always in progress.

Learn more biomedcentral.com/submissions 